\title{
RANCANG BANGUN DAN APLIKASI PENGERINGAN IKAN TERI DENGAN PENGERING BERINSULASI
}

\author{
Wahyuningsih $^{1}$, R TD Wisnu Broto ${ }^{2}$ \\ ${ }^{1}$ laboratorium Teknologi Pangan,PSD III Teknik Kimia Undip \\ ${ }^{2}$ laboratorium Operasi Teknik Kimia ,PSD III Teknik Kimia Undip
}

\begin{abstract}
Basic Principles of Design Tools dryer, variables that must be considered among other properties properties of the material to be dried, the characteristic drying of the material, heat flow, quality of products, the facilities around, the capacity of the tool, From factors - these factors are expected to get drier the performance of a very powerful and effective.

The aim of this study was to design and build insulated fish dryers to improve the traditional fish drying process, enhance nutritional value, food safety and hygiene and to apply drier at drying anchovy (Stolephorus heterolobua), as well as to know the quantity of omega-3 fatty acids.

Drier the result of design, size $1 \mathrm{~m} \times 1.2 \mathrm{~m} \times 1,75 \mathrm{~m}$, collector size of $1.2 \mathrm{mx} 0.6 \mathrm{~m}$, can be used for drying fish (Stolephorus heterolobua) hygienically and maintain the quality of products Lama drying 72 hours results dried fish that meets dtandar water content, for solar heating water content of 2.45\%, for artificial heating water content of $2.65 \%$ preferred product is dried with saline $6 \%$ On acceptable products value EPA $0.5972 \mathrm{gr} / 100 \mathrm{~g}$ and $0.4032 \mathrm{~g} \mathrm{DHA} / 100 \mathrm{~g}$, the value of TBA $1.21 \mathrm{mgr} / \mathrm{kg}, \mathrm{TVB}:$ 7,04mgr N/ lo0gr, TMA: $5.11 \% \mathrm{~N} \mathrm{mgr}$
\end{abstract}

Keyword : Design Tools dryer, insulated fish dryers

Abstrak

Prinsip Dasar Rancang Bangun Alat Pengering, peubah-peubah yang harus diperhatikan antara lain Sifat - sifat bahan yang akan dikeringkan,karakteristik pengeringan dari bahan, aliran panas, kualitas produk, fasilitas sekeliling,kapasitas alat. Dari faktor - faktor tersebut diharapkan untuk mendapatkan alat pengering dengan kinerja yang berdayaguna dan berhasil guna.

Tujuan dari penelitian ini adalah merancang dan membangun alat pengering ikan berinsulasi untuk memperbaiki proses pengeringan ikan tradisional,meningkatkan nilai gizi, hygiene dan keamanan pangan dan mengaplikasikan alat pengering pada pengeringan ikan teri (Stolephorus heterolobua), serta mengetahui kwantitas asam lemak omega-3.

Kesimpulan dari penelitian ini adalah: Alat pengering hasil rancang bangun, ukuran $1 m x \quad 1,2 m$ x1,75 m, ukuran kolektor 1,2 m x 0,6 m, dapat dimanfaatkan untuk mengeringkan ikan teri (Stolephorus heterolobua) secara higienis dan mempertahankan kualitas produk Lama pengeringan 72 jam memberikan hasil ikan kering yang memenuhi dtandar kadar air, untuk pemanas surya kadar air 2,45\%, untuk pemanas buatan kadar air 2,65\% Produk yang disukai adalah pengeringan dengan kadar garam 6\% Pada produk yang dapat diterima memberikan nilai EPA 0,5972 gr/l00 gr, dan DHA 0,4032 gr/l00 gr, nilai TBA 1,21 mgr/kg, TVB : 7,04mgr N/100gr,TMA : 5,11\% $\operatorname{mgr} N$

Kata kunci : Rancang Bangun Alat Pengering, alat pengering ikan berinsulasi

\section{PENDAHULUAN}

Dewasa ini kemajuan teknologi pengolahan khususnya dibidang hasil perikanan meningkat dengan pesat. Hal ini menuntut peningkatan pengetahuan peneliti, ilmuwan dan masyarakat tentang teknologi pengolahan ikan, sehingga pengolahan hasil perikanan mempunyai arti sosial ekonomi yang penting bagi nelayan, petani ikan, pengolah serta pedagang ikan (Ilyas, 2003)Ikan dan hasil-hasil perikanan lainnya merupakan highly perisable food, maka nilai pasar hasil awetan dan olahannya ditentukan oleh derajad kesegaran dan daya awetnya (Buckle, et al, 1983, dalam Hadiwiyoto, 2003). Salah satu hal untuk mengatasi hal tersebut adalah metode pengawetan.(Hudaya dan Darajad, 2009). 
Pada produksi hasil laut perubahan kualitas dari segi rasa, bau, tekstur, dan warna dapat terjadi akibat pertumbuhan bakteri. Perubahan kualitas tersebut kecepatannya tergantung dari kadar bakteri awal, kondisi penyimpanan, suhu, kelembaban dan tekanan atmosfir.

Produk hasil laut bersifat lebih mudah terdekomposisi dibandingkan produk berprotein tinggi lainnya. Hal ini disebabkan karena : Beberapa produk hasil laut mengandung kadar osmoregulator tinggi dalam bentuk non protein nitrogen seperti trimetil amin, urea, asam amino dan lain sebagainya yang merupakan media yang baik untuk pertumbuhan bakteri Produksi hasil laut dipanen dari air yang dingin sehingga flora bakteri tidak mudah dihambat oleh perlakuan suhu dingin dibanding flora hewan atau tanaman.

Keamanan produksi hasil laut terutama tergantung dari kemungkinan tercemar mikrobia patogen, atau disebabkan oleh histamin akibat proses penanganan yang kurang tepat. Masalah penyediaan ikan yang berkualitas tinggi, baik untuk konsumsi langsung maupun untuk bahan baku industri semakin mendesak dewasa ini, sehingga Kendala yang dihadapi produsen ikan asin saat ini adalah proses pengeringan, antara lain : semakin terbatasnya lahan untuk menjemur ikan, karena lahan kosong digunakan untuk tempat tinggal. Pada saat ini ikan dijemur diatas anyaman bambu dan penjemuran dibiarkan terbuka, ditempatkan diatas pembuangan sampah (seperti pada lampiran). Hal diatas tentu saja sangat tidak higienis. Pada musim penghujan ikan tidak segera kering, hal ini mengakibatkan ikan menjadi busuk, sehingga kualitas ikan asin akan menurun, sebagai akibatnya ikan tersebut tidak aman dikonsumsi. Mengingat hal diatas maka perlu diteliti suatu alat pengering ikan berinsulasi yang dapat berfungsi tanpa dipengaruhi musim serta tidak tergantung dimana alat tersebut diletakkan.

Penelitian ini dilakukan dengan tahapan berikut :

Perancang alat pengering untuk kapasitas $20 \mathrm{Kg}$, mengaplikasikan alat pengering untuk pengeringan ikan teri. Parameter yang diuji pada penelitian ini adalah laju pengeringan terhadap waktu dengan panas matahari, maupun dengan panas buatan sampai batas kadar air ikan yang dikeringkan mencapai 2,5\% (Tabrani Rob, 2007). Kualitas ikan meliputi : Kehilangan berat setelah pengeringan (metode pengukuran berat basah dan berat kering), kandungan asam lemak omega-3 (khromatographi), Kerusakan protein (metode TVB), kerusakan lemak (metode TBA), tingkat kebusukan (metode TMAO)

\section{HASIL DAN PEMBAHASAN}

Hasil penelitian meliputi : Rancang bangun alat pengering berinsulasi, Aplikasi alat pengering berinsulasi untuk mengeringkan ikan teri (Stolephorus heterolobua).

Rancang bangun alat pengering berinsulasi : Pada penelitian ini telah dirancang alat pengering ikan berinsulasi menggunakan tenaga surya yang dilengkapi dengan panas buatan berupa lampu tekan, dengan ukuran $1 \mathrm{~m} \times 1,2 \mathrm{~m} \times 1,75 \mathrm{~m}$, sedang ukuran kolektor 1,2 $\mathrm{m} \times 0,6 \mathrm{~m}$, terpasang pada sisi kiri dan kanan alat pengering. Pada penelitian ini untuk waktu pengeringan sampai 72 jam EPA dan DHA semakin menurun dengan bertambahnya konsentrasi garam, kondisi optimum tercapai pada konsentrasi garam 6\%, konsentrasi diatas $6 \%$ kadar EPA dan DHA akan menurun hal ini disebabkan sifat garam yang higroskopis, sehingga akan menarik komponen dalam sel termasuk asam lemak Pada pengujian kerusakan lemak terlihat bahwa makin tinggi konsentrasi garam yang digunakan kerusakan lemak (angka TBA) akan semakin rendah, hal ini disebabkan sifat garam memberikan keadaan osmotic untuk lingkungannya sehingga mikroba perusak akan mati, kecuali mikroba yang tahan terhadap tekanan osmose tinggi, dan juga dengan konsentrasi garam tinggi akan mencegah autolisis sedang lama pengeringan juga akan menaikkan angka TBA, hal ini disebabkan laju oksidasi lemak dipacu oleh suhu. Angka TBA tertinggi pada penelitian ini yaitu konsentrasi garam 2\%, waktu pemanasan 72 jam, yakni sebesar 3,11 mgr/100gr, sedang penggaraman konsentrasi10\% memberikan angka TBA 1,61mgr/100gr, dan angka TBA awal 
METANA, Vol. 10 No. 01, Juli 2014, Hal. 34-38

sample $0,37 \mathrm{mgr} / 100 \mathrm{gr}$, sedang angka TBA standar untuk ikan yang masih layak

dikonsumsi sebesar

(Gokalp,2003).

$3-4 m g r / 100 g r$

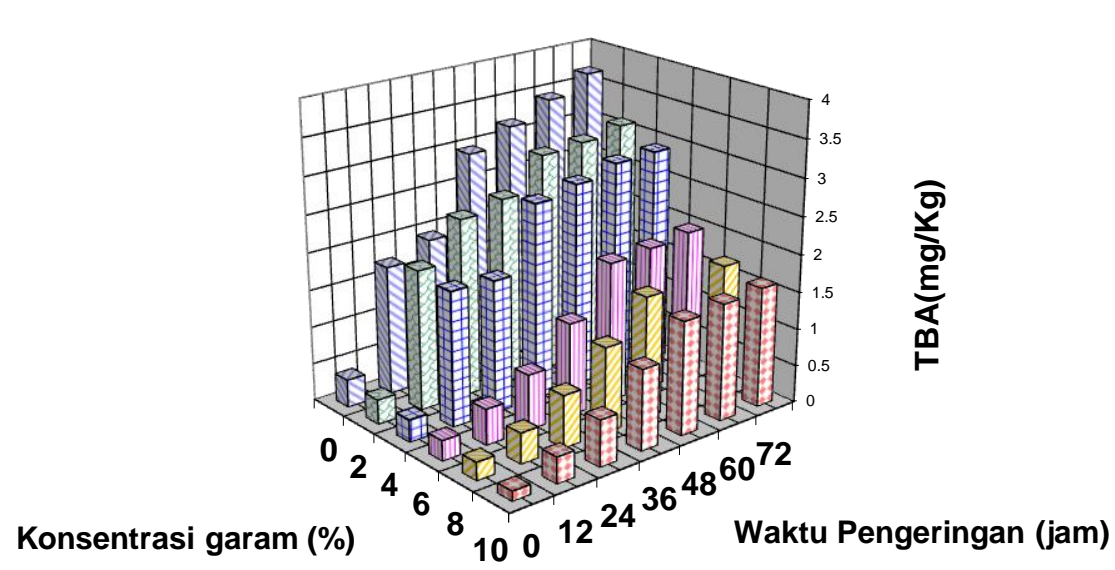

Gambar 1 : Hubungan konsentrasi garam, waktu pengeringan terhadap angka TBA

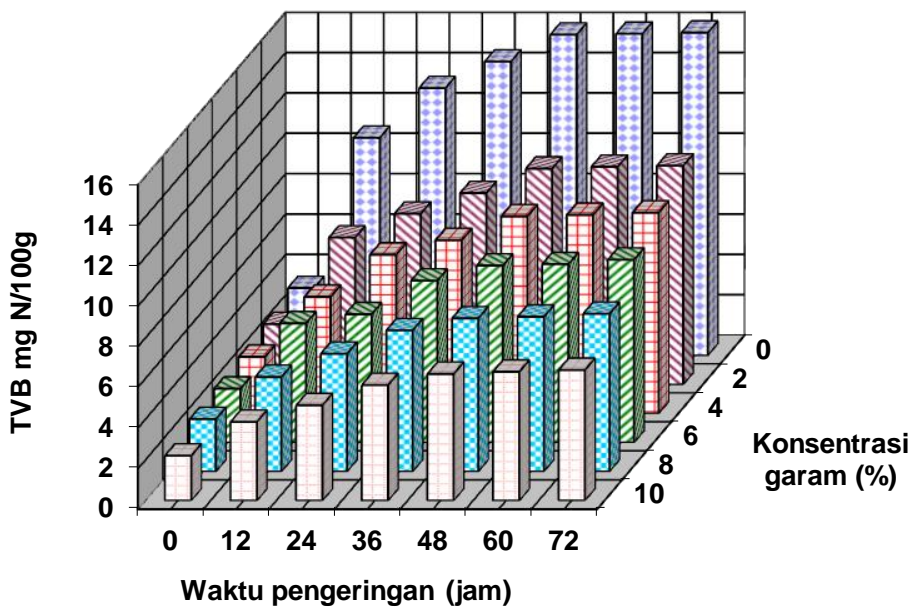

Gambar2 : hubungan waktu pengeringan, konsentrasi garam terhadap nilai TVB

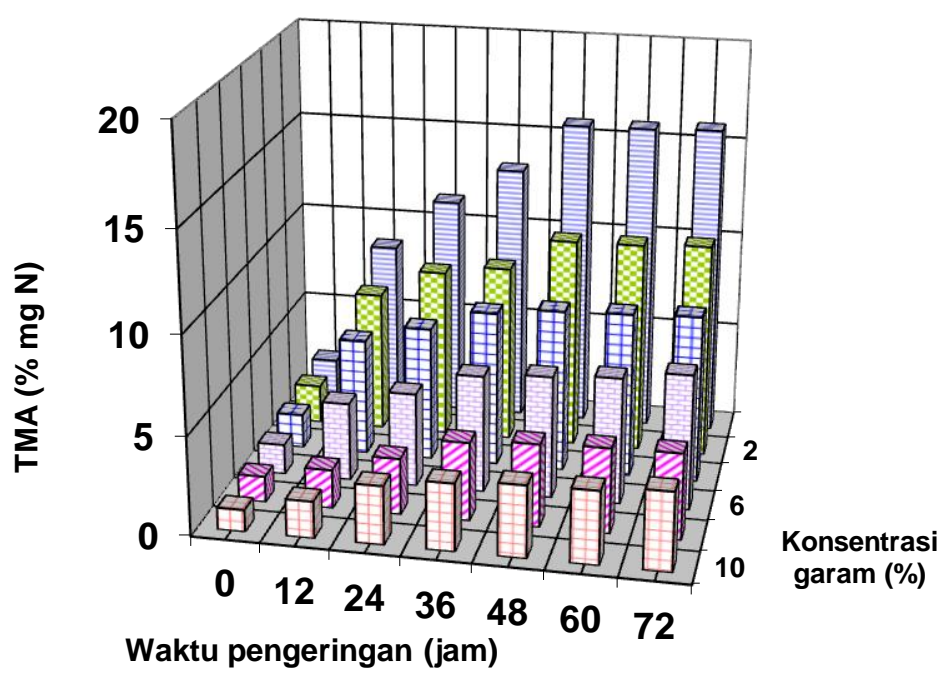

Gambar 3 : Hubungan antara waktu pengeringan, konsentrasi garam terhadap nilai TMA 


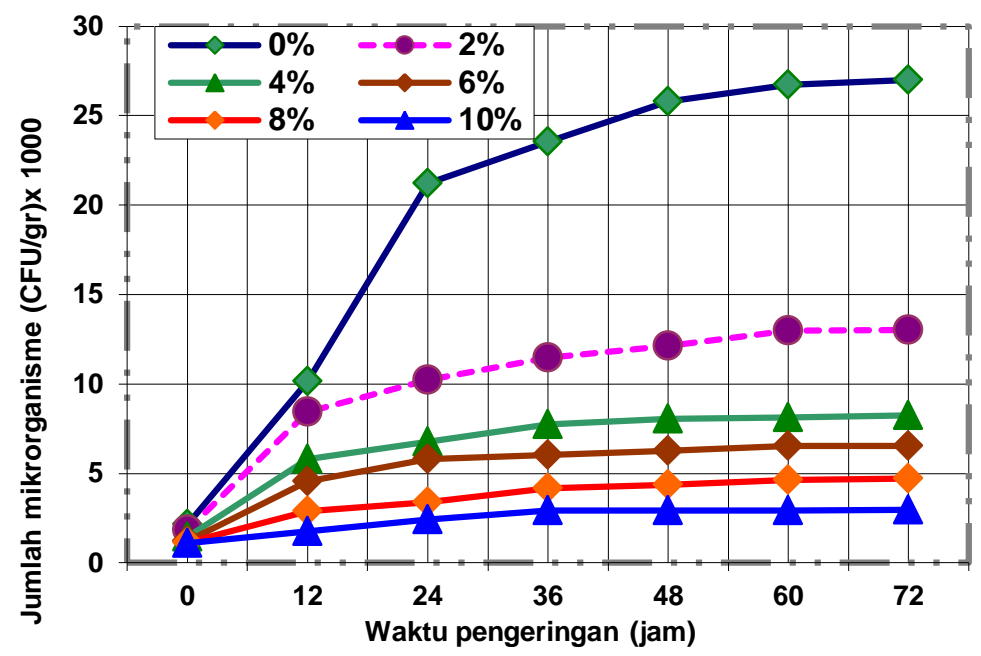

Gambar 4 : Hubungan antara waktu pengeringan, konsentrasi garam terhadap nilai TPC

\section{KESIMPULAN}

Alat pengering hasi rancang bangun, ukuran $1 \mathrm{~m}$ x $1,2 \mathrm{~m} \quad \mathrm{x} 1,75 \mathrm{~m}$, ukuran kolektor $1,2 \mathrm{mx} \quad 0,6 \mathrm{~m}$, dapat dimanfaatkan untuk mengeringkan ikan teri (Stolephorus heterolobua) secara higienis dan mempertahankan kualitas produk Lama pengeringan 72 jam memberikan hasil ikan kering yang memenuhi dtandar kadar air , untuk pemanas surya kadar air $2,45 \%$, untuk pemanas buatan kadar air 2,65\% Produk yang disukai adalah pengeringan dengan kadar garam 6\% Pada produk yang dapat diterima memberikan nilai EPA 0,5972 gr/100 gr, dan DHA 0,4032 gr/100 gr, nilai TBA $1,21 \mathrm{mgr} / \mathrm{kg}$, TVB : $7,04 \mathrm{mgr}$ N/100gr,TMA : $5,11 \%$ mgr N

\section{DAFTAR PUSTAKA}

Abbas Siregar, 2000, Ikan Asin, Kanisius Yogyakarta

Adnan, 1999, Teknik khromatographi untuk penelitian bahan pangan, PAU Pangan Gizi, UGM Yogyakarta

Agus Irawan, 2005, Pengawetan Ikan Dan Hasil Perikanan Cara Mengawetkan Secara Tradisional dan Modern, CV.Aneka, Solo

Ashgar, A., J.I. Gray, D.J. Buckley, A.M. Pearson, and A.M. Booren. 2008.
Perspective on Warmed Over Flavor. Food Technol. 42(6):102

Bender, A.E. 2002. Processing Damage to Protein Food : A Review. J. Food Technol. 7:239-250.

Bligh, E.G.; S.J. Shaw and A.D. Woyewoda. 1988. Effect of Drying and Smoking on Lipids of Fish. Fish Smoking and Drying. Edited by Burt, J.R. Elsevier Applied Science.

Buckle, k.a., r.a. Edward, G.H. Fleet dan M.M. Woodom. 1985. Ilmu Pangan. Terjemahan. UI-Press, Jakarta

Connel, J.J. 1975. Control of Fish Quality Fishing, News (Book) Ltd, Surrey, London

Cuppet, S.L.; J.I. Gray; A.M. Booren; J.F. Price and M.A. Stachiw. 1989. Effect of Processing Variables on Lipid Stability in Smoked Great Lake Whitefish. J. Food Sci. 54(1):52-54.

Cutting, C.L. 1965. Smoking. Fish as Food. Edited by Borgstrom, G. Vol. III Processing : Part I. Three Academic Press. New York, San Fransisco, London. 55-101. 
Faraouk, M.M.; J.F. Price and A.M. Salih. 2001. Effect of $\mathrm{Fe}^{2+}$, Salt, Cooking and Shredded Coffi on Thiobarbituric Acid (TBA) Numbers in Ground Beef. J.Food Sci. 56(1):172-174.

Filmore E.Binder, 1992, Statistical methods for food and agriculture, Avi publishing Co Inc. Wesport, Connecticut

Gokalp, H.Y.; H.W.Ockerman; R.F. Plimpton and W.J.Harper. 2003. Fatty Acid of Neutral and Phospholipids, Rancidity Scores and TBA Values as Influenced by Packaging and Storage. J. Food Sci. 48:829-834.

Hadiwiyoto.S, . 1993. Tehnologi Pengolahan Hasil Perikanan Jilid.I. Liberty. Yogyakarta.

Hadiwiyoto.S, 2007, Hasil perikanan : manfaat dan keamannya serta implikasinya pada kesehatan Tinjauan dari sisi teknologi, pengolahan dan lingkungan, Agritech 17 (3), 28-41

Hudaya, S. Dan S.S. Daradjat. 2007. Dasar-dasar Pengawetan Jilid II. Departemen Pendidikan dan Kebudayaan. Direktorat Menengah Kejuruan. Jakarta

Ilyas, S., 2003. Teknology Pemanfaatan Lemuru Selat Bali. Prosiding Seminar Perikanan Lemuru, 18 - 21 Januari 1982, Banyuwangi.

Kanoni, S., M. Astuti dan S. Naruki, 1999. Evaluasi Kandungan Histamin Ikan Peda Yang Beredar di Pasar Yogyakarta dan Pengaruhnya Terhadap Histologi Kelenjar Hati Tikus. PAU Pangan dan Gizi UGM. Yogyakarta

Love,J. 1988. Sensory Analysis of Warmed - Over Flavour in Meat. Food Technol 426(140-143)
Moel janto, R., 1982. Penanganan Ikan Segar. Penebar Swadaya, Jakarta

Muhilal, 1995, Asam lemak omega-3 dan manfaatnya untuk kesehatan, prosiding seminar hasil perikanan, Puslitbang, Jakarta, 53-67

Peterson WR, J.J,Wurdhesen, 1999, Total lipid determination using High LiquidPerformanceChromatograpy J.Food Sci, 44 :994-997

Setiabudi.,1988, Kumpulan Hasil - Hasil Penelitian dan Pengembangan Perikanan,. Badan Penelitian dan Pengembangan Pertanian. Bekerja sama dengan FRDP/USAID

Shinta Teviningrum, 2004, Makanan formula untuk sakit gula, Intisari Maret 2004, PT Gramedia Jakarta

Sinclair. J.A., 1993, The nutrional significant of omega-3 polyunsaturated fatty acid for human, Asean food journal 8, 3-18

Simopoulus. A.P.,1991, Omega-3 fatty acid in health and disease and in growth and development, American journal Chem nutrition, 54, 438463

Siu, G.M. and H.H. Draper. 1978. A Survey of The Malonaldehyde Content of Retail Meats and Fish. J. Food Sci. 43:1147-1149

Stansby, M.E. and Olcott. 1963. Composition of Fish. In Industrial Fishery Technology, Reinhold Publishing Corporation. 339-349.

Tatang Djuhanda, 1999, Dunia Ikan, Armico Bandung Tabarani Rob, 2007, Teknologi Hasil Perairan, Panca Abdi Pakanbaru Tri Margono, Detty Suryati, Sri Hartinah, 2000, Pengeringan ikan, PDII LIPI 